DOI: $10.7596 /$ taksad.v2i2.236

\title{
An Analysis of Maxim Gorky's Short Story Her Lover
}

\begin{abstract}
This paper debates three views in Maxim Gorky's short story Her Lover. The first one is human loneliness, lack of communication, fragmented and lost identity in modern industrialized Russian society, which was actually a general view in the early decades of the twentieth century. Secondly, Gorky endows his fictional character Teresa with the Romantic energy which enables her to survive her misery and loneliness by inventing an imaginary lover. Finally, the paper examines the views of prejudice and "self-sufficiency" which put serious hurdles before real communication and thus cause the spiritual and moral decay in social life and relationships.
\end{abstract}

Key Words: Loneliness, identity, Romanticism, prejudice and self-sufficiency.

\footnotetext{
${ }^{*}$ This paper was presented at the First International Week on English Studies Conference, May 27-31, 2013, Karabuk University, Karabuk-Turkey.

${ }^{* *}$ Professor of English Literature, Karabuk University, Faculty of Letters, Department of English Language and Literature, Karabuk-Turkey. The author can be reached at gunesali1@gmail.com
} 


\section{Introduction}

My interest in Maxim Gorky's short story Her Lover (1917) grew during 2011-2012 academic year, while teaching the short story I and II courses in the department of English Language and Literature at Karabuk University, Karabuk-Turkey. Soon after I had been assigned to teach these courses, I decided to take short stories from the literatures of different countries not only to show my students the various practices of the short-story writing in different countries because the earliest pioneering examples of the short-story writing in the nineteenth century come from various authors in different places such as Edgar Allan Poe in America, Guy de Maupassant in France, and Anton Chekhov in Russia, and so on, even though the history of the short story is actually older, but I also wished to have my students expand their perceptions and understanding of life through their study of diverse cultures and artistic practices across the world. Then I started searching for the short stories as the twosemester short story study entailed around 30 short stories. While wobbling with indecision about which short stories I could have included into my teaching, I encountered Maxim Gorky's short story Her Lover, which has really captivated my interest because I was actually looking for an emotional Romantic love story to go beyond the routine of study by avoiding the wearisome study of the technical aspects of the short stories such as character, narrative technique, language and so on, which sometimes bores and do not allow us to examine the story in other facets as a result of the level of education, yet I found myself completely in a different situation in that I saw that Gorky deals with love, yet he uses it for a different purpose linked to some important interacting moral and social views which may associate with his own life and time in the first half of the twentieth century as well as with the human life in general.

My ensuing readings and research, concerning Her Lovers, have deeply focused upon these views, but I have seen in my research that Gorky critics have totally neglected his short story Her Lover in their analysis, but they have analysed his other short stories, novels, plays and political views (Muchnic, 1963; Karlinsky, 1966 and Balasubramanian, 1994). In his review article about Gorky's plays, for example, Francis J. Whitfield points out that "the short individual prefaces, for the most part, hints about the background of each play and bits of information unfamiliar to the foreign reader" (1946: 111). Whitfield continues to state that "in the play [Enemies]...among the workers themselves, as in the case of Levshin, ideas have currency which have more in common with the concepts of socialism", and thus "the reader is entitled to know that some controversy has arisen about these interpretations" (111-2). In addition, Emanuel Salgaller argues: 
Although venerated in the Soviet Union, Maxim Gorky is largely forgotten in the West. Except for his Lower Depths, which is occasionally performed, and for some of his short stories, his works find little response outside the Communist world. His Mother, which is celebrated in Soviet Russia as a "masterpiece of early proletarian writing," bores us by its tendentiousness, its strident tone, and the stereotyped characterization of the main male protagonist, Pavel Vlassov. Of his later works only the autobiographical writings and parts of Klinm Samngin retain some of their freshness. The same charge of neglect can be applied to critical and biographical writing (1963: 370).

Salgaller also finds this lack of attention for Gorky "regrettable" because "Gorky was a remarkable literary and psychological phenomenon", and for him, Gorky "was the first major writer to emerge from Russia's "lower depths," to break fully with the classical and sophisticated traditions of the past, to put the vagabond (at times in a highly romanticized form) squarely into the centre of literary creation", and finally, Salgaller maintains that "Gorky's neglect in the West leaves the field wide open to Soviet literary pundits, who exaggerate his importance beyond all measure and force him and his works into prescribed pattern" (370). As for Gorky's short story Her Lover, nevertheless, critics have overlooked it in their assessment of his works. The story is included in the collections. For example, Thomas Seltzer put Gorky's Her Lover in the collection of Best Russian Short Stories (1917), and later on in 1961, Roger B. Goodman also included it in 75 Short Masterpieces: Stories from the World's Literature.

Among important interacting moral and social issues, however, this paper debates three views in Gorky's short story Her Lover. The first one is human loneliness, lack of communication, fragmented and lost identity in modern industrialized Russian society, which was actually a general view in the early decades of the twentieth century under the label of modernist perception of identity. Secondly, it focuses upon the Romantic aspect in that Gorky endows his fictional character Teresa with the Romantic energy which enables her to survive her misery and loneliness by inventing an imaginary lover. Finally, the paper examines the view of prejudice or what Gorky calls "self-sufficiency", which puts serious hurdles before real communication and thus causes the spiritual and moral decay in social life and relationships.

The early decades of the twentieth century witnessed a radical shift in the modernist perception of human identity in that human identity was viewed as being lonely with lack of human communication, fragmentation and alienation in life and social relationship. These views play an important role in Gorky's short story Her Lover, and he represents these views of identity in the story through the life of his fictional female character Teresa. The story begins with a sense of doubt, concerning her life and identity as her "repute is questionable" (Gorky, 1917: 232). The word "questionable" immediately arouses our curiosity, which actually continues till the end of the story. Teresa is "a Pole" and lives alone in a derelict 
apartment in Moscow. She is "a tallish, powerfully-built brunette, with black, bushy eyebrows and a large coarse face as if carved out by a hatchet-the bestial gleam of her dark eyes, her thick bass voice, her cabman-like gait and her immense muscular vigour, worthy of a fishwife" (232). Her outward appearance frightens the unnamed student narrator of the story who lives next to her in the same building, so that he never leaves his door open when he knows her to be at home. Sometimes he meets her on the staircase or in the yard, yet their meeting worries him further when she smiles upon him since her "smile" "seemed to me to be sly and cynical. Occasionally, I saw her drunk, with bleary eyes, tousled hair, and a particularly hideous grin. On such occasions she would speak to me" (232; emphasis added):

"How d'ye do, Mr. Student!" and her stupid laugh would still further intensify my loathing of her. I should have liked to have changed my quarters in order to have avoided such encounters and greetings; but my little chamber was a nice one, and there was such a wide view from the window, and it was always so quiet in the street below-so I endured (232).

As the quotations above illuminate, there seems something wrong with Teresa, which obviously leads her to live an unusual life; it is unusual because her "reputation is questionable", she lives alone and seems to the boy "sly and cynical", and what is more, she drinks heavily with "bleary eyes, tousled hair" and "hideous grin", giving an impression that she trying to get rid of something which profoundly disturbs and causes her to act in an unusual way. As the story unfolds, Teresa's disturbed situation gradually becomes clearer and clearer for the reader. For example, one day Teresa visits the student as he is "trying to find some sort of excuse for not attending my class" (232). She appears to the student "confused and supplicatory" and asks him at once for a favour in a "beseeching, soft, timid" manner (233). She wants him to write a letter to her boyfriend Boles, and in return, she promises to mend his "shirts or trousers" (234), and the boy writes the letter, which says: "My dear Boles...my darling...my faithful lover. May the Mother of God protect thee! Thou heart of gold, why hast thou not written for such a long time to thy sorrowing little dove, Teresa?" (233). The letter is very short; it indicates that Teresa's boyfriend, who lives far away, has not written to her for a long time, which apparently makes her feel sad, unhappy, lonely and abandoned in her life, so that the letter becomes a means of communication between Teresa and Boles or a means by which she reminds her lover of her presence and love. Moreover, the letter to Boles psychologically soothes Teresa's troubled psyche because it psychologically excites and gives her pleasure; it helps her to keep her feeling fresh and elevated because the letter gives her a sense that she loves Boles and vice versa.

The mystery related to Teresa's lover is resolved two weeks later when she wants the student to write another letter. But the funny thing is that now she begs him to write the second letter not from Teresa to Boles but from Boles to Teresa: "Stupid that I am! It is not for me, Mr. Student, I beg your pardon. It is for a friend of mine, that is to say, not a friend but an acquaintance-a man acquaintance. He has a sweetheart just like me here, Teresa. That's how it 
is. Will you, sir, write a letter to this Teresa?" (234-5). The boy is surprised very much but gets angry with her due to the fact that she strives either to keep him busy or to be close to him or to mislead him: "Look here, my lady," I said, "there are no Boleses or Teresas at all, and you've been telling me a pack of lies. Don't you come sneaking about me any longer. I have no wish whatever to cultivate your acquaintance. Do you understand?" (235; emphasis added) Upon the refusal of the boy to get involved in such a comic and stupid situation by writing meaningless letters, Teresa grows strangely "terrified and distraught", giving the boy an impression that "she wanted to say something and couldn't", and then she leaves him at once, just saying, "Mr. Student!" (235).

However, soon after, Gorky bestows a humane feeling upon the boy, and he immediately regrets acting in an aggressive indifferent manner towards her and comes to realize that he has made "a great mistake in suspecting her of wishing to draw me from the path of righteousness. It was evidently something very different" (235; emphasis added). The feeling that "It was evidently something very different" forces him to call upon Teresa for removing the "very unpleasant feeling" (235), and then he visits her in her apartment. The boy finds her "sitting at the table, leaning on her elbows, with her head in her hands", and then she clarifies the situation:

“Look you, now! It's like this. There's no Boles at all, and there's no Teresa either. But what's that to you? Is it a hard thing for you to draw your pen over paper? Eh? Ah, and you, too! Still such a little fair-haired boy! There's nobody at all, neither Boles, nor Teresa, only me. There you have it, and much good may it do you!"

"Pardon me!" said I, altogether flabbergasted by such a reception, "what is it all about? There's no Boles, you say?"

"No. So it is."

"And no Teresa either?"

“And no Teresa. I'm Teresa” (235).

That there is "no Boles" and there is "no Teresa" really surprises the boy; he innocently tries to find meaning behind all these attempts of Teresa: that is, why does she attempt to act in such a silly way? Having observed the boy with palpable wonder and curiosity in his eyes, Teresa answers the question in an offended tone as if she knew all the things which pass through the mind of the boy:

"If it was so hard for you to write to Boles, look, there's your letter, take it! Others will write for me."

I looked. In her hand was my letter to Boles. Phew! 
"Listen, Teresa! What is the meaning of all this? Why must you get others to write for you when I have already written it, and you haven't sent it?"

"Sent it where?"

"Why, to this-Boles."

“There's no such person.”

I absolutely did not understand it. There was nothing for me but to spit and go. Then she explained.

"What is it?" she said, still offended. "There's no such person, I tell you," and she extended her arms as if she herself did not understand why there should be no such person. "But I wanted him to be... Am I then not a human creature like the rest of them? Yes, yes, I know, I know, of course...Yet no harm was done to any one by my writing to him that I can see..."

"Pardon me-to whom?"

“To Boles, of course."

"But he doesn't exist."

"Alas! alas! But what if he doesn't? He doesn't exist, but he might! I write to him, and it looks as if he did exist. And Teresa-that's me, and he replies to me, and then I write to him again..."

I understood at last. And I felt so sick, so miserable, so ashamed, somehow. Alongside of me, not three yards away, lived a human creature who had nobody in the world to treat her kindly, affectionately, and this human being had invented a friend for herself!

"Look, now! You wrote me a letter to Boles, and I gave it to someone else to read it to me; and when they read it to me I listened and fancied that Boles was there. And I asked you to write me a letter from Boles to Teresa-that is to me. When they write such a letter for me, and read it to me, I feel quite sure that Boles is there. And life grows easier for me in consequence" (235-7, emphasis added).

The boy eventually understands Teresa's real situation as well as the reason behind her desire to invent "a friend for herself" and write letters to him. From that moment onward, he regularly writes letter for her:

And from thenceforth, regularly, twice a week, I wrote a letter to Boles, and an answer from Boles to Teresa. I wrote those answers well... She, of course, listened to them, and wept like anything, roared, I should say, with her bass voice. And in return for my thus moving her 
to tears by real letters from the imaginary Boles, she began to mend the holes I had in my socks, shirts, and other articles of clothing (237).

For me, this long quotation is of importance in two ways. First, the way Gorky represents Teresa in Her Lover illuminates the modernist perception of identity in that she, like James Duffy in James Joyce's short story A Painful Case (1914), seems lonely, isolated, and fragmented in her life without a proper contact with the outside world. Human loneliness, lack of communication, fragmented and lost identity are main features of characterization and identity in modernist literature in that the stable and fixed view of traditional character disappears since as William Butler Yeats writes in his poem The Second Coming (1920), "Things fall apart; the centre cannot hold" any meaning for individuals in the early decades of the twentieth century due to some radical shifts and developments in social, political, scientific, philosophical and artistic domains of life (Abrams, 1979: 1973). As for the modernist perception of character, moreover, there is little information about Teresa's life on contrary to that of a traditional character; our knowledge is very limited about her as in the life of Gusev in Anton Chekhov's short story Gusev (1890). What we know about Teresa is as follows: her "reputation is questionable", even though it is not clarified throughout the story; besides her brief physical description, she is "a Pole" and lives in an apartment in Moscow next to a university student; she gets the student boy to write letters to an imaginary lover not only to communicate with the outside world but also to get rid of her boredom and loneliness in her life, and eventually "about three months after this history [with the boy] began, they put her in prison for something or other. No doubt by this time she is dead" (237). Is this enough to know exactly the life of a person? No, it is not really. Secondly, the quotation above is also closely related to Gorky's own political view as well as to his view of socialist realism, which he employed in his works. In line with his political and socialist views as Tovah Yedlin states in Maxim Gorky: A Political Biography (1999), Gorky often represented the proletarian workers, impoverished, fallen, tramps, social outcast and the people on the margins of society, together with their hardship, marginalization, and humiliations in life, fragmented identities and inwardly inspiring humanity. In Her Lover, Gorky represents Teresa in a way that she is obviously lonely and outcast with "nobody in the world to treat her kindly, affectionately", which is actually the need of anyone in the world. By this view, in fact, Gorky indirectly and artistically brings the condition of the "fallen" class to the attention of Russian society and criticizes the indifferent attitudes of both state and public towards such people; he also reminds the state indirectly of its responsibility in the story.

Gorky's representation of Teresa as being friendless, abandoned, ugly and outcast woman character, who strives to get rid of her loneliness and then to communicate with the outside society and then to gain peace by inventing her own strange method, leads us to the second view which has enthralled me in Her Lover, the view which is visibly related to the Romantic energy which Gorky bestows upon Teresa when she desires and imagines a sense of 
unity, wholeness, happiness, harmony and meaning in her vision and life. Teresa's situation brings to mind that of a Romantic character: that is, when a Romantic character is in a deep psychological conflict, crisis and confusion, s/he often desires to soothe her/his psyche by crossing imaginatively the border of the physical existence through the creation of an imaginary space where s/he feels happy and peaceful. As in the actual life, the Romantic character seeks a kind of psychological balance and unity to survive the crippling effect of conflict and crisis in her/his psyche; otherwise, s/he may undergo neurotic disorders in life.

Likewise, in Her Lover, Gorky represents Teresa as a lonely, outcast, and friendless woman without a proper contact with anyone else outside; there is "nobody in the world to treat her kindly, affectionately" (237). This situation obviously not only cripples her psychology and feeling but also causes her to fall apart in her life, yet Teresa, like a Romantic character, passionately longs for being at the centre of life and meaning; she energetically craves to enjoy the beauty of life because as Gorky writes in the story, "the more a human creature has tasted of bitter things the more it hungers after the sweet things of life" (237; emphasis added), which is truly a Romantic position. For this purpose, therefore, Gorky romantically enables Teresa to invent an imaginary boyfriend as if he were real from back home not only to fight her loneliness and misery but also to keep herself alive, fresh and happy in a brutally indifferent and relentless world:

... "There's no such person, I tell you," and she extended her arms as if she herself did not understand why there should be no such person. "But I wanted him to be... Am I then not a human creature like the rest of them? Yes, yes, I know, I know, of course...Yet no harm was done to any one by my writing to him that I can see..."

"Pardon me-to whom?"

"To Boles, of course."

"But he doesn't exist."

“Alas! alas! But what if he doesn't? He doesn't exist, but he might! I write to him, and it looks as if he did exist. And Teresa-that's me, and he replies to me, and then I write to him again..."

I understood at last. And I felt so sick, so miserable, so ashamed, somehow. Alongside of me, not three yards away, lived a human creature who had nobody in the world to treat her kindly, affectionately, and this human being had invented a friend for herself!

"Look, now! you wrote me a letter to Boles, and I gave it to someone else to read it to me; and when they read it to me I listened and fancied that Boles was there. And I asked you to write me a letter from Boles to Teresa-that is to me. When they write such a letter for me, and read it to me, I feel quite sure that Boles is there. And life grows easier for me in consequence" (235-7, emphasis added). 
As the quotation clearly suggests, Teresa is terribly lonely and alienated in her life; there is "nobody in the world to treat her kindly, affectionately", so that she imaginatively "invented a friend for herself" not only to communicate with but also to be at the centre of life and meaning with excitement, fancy and happiness, even though she is sure that Boles does not exist. Under such as a constant fancy and vision of having "a friend for herself", Teresa tells the boy that "And I asked you to write me a letter from Boles to Teresa-that is to me. When they write such a letter for me, and read it to me, I feel quite sure that Boles is there. And life grows easier for me in consequence". Teresa does not want much in life but a kind of life which "grows easier" for her in the face of difficulties and pitilessness imposed upon her in the actual life. In addition, having such an invented romantic "friend" also enables Teresa psychologically to create an imaginative space where she holds on tightly to life without the anxieties and thorns of the physical life, and she also strives to escape from an intolerable harshness and reality of her life. In this respect, the way Teresa invents a friend for herself to make her life "grow easier" could be seen in our life as well since we sometimes also tend to escape the intolerable reality of our lives through our fancies and dreams once we are in psychological crisis. Otherwise, life also becomes unbearable for us.

The third point in Her Lover the paper discusses is the view of prejudice, or biased attitude towards others, or what Gorky calls in the story, "self-sufficiency" (237), which makes us blind and victim in life once we attempt to communicate and establish warm relationship with one another in the actual life. In $O E D$, prejudice is given as "an unreasonable dislike of or preference for a person, group, custom, etc, especially when it is based on their race, religion, sex, etc". Moreover, Gordon Allport defined prejudice as a "feeling, favourable or unfavourable, toward a person or thing, prior to, or not based on, actual experience" (1979: 6). As seen in these definitions, prejudice is often linked to prejudgment which frequently blocks our way of understanding one another and imprisons us within the walls of "an unreasonable dislike" and "self-sufficiency", in which we think that everybody is well because our own "self-sufficiency" as well as the welfare of our narrow circle of people satisfy and make us happy, even though the reality is just opposite. By this approach, unfortunately, we not only condemn ourselves to moral and spiritual decay in our relationship with other people around us, but it also avoids real communication and obviously brings about misunderstanding, indifference and aloofness in social life.

In Her Lover, similarly, Gorky represents the view of prejudice or "self-sufficiency" when Teresa endeavours to contact the nameless young university student in Moscow and asks him to write a letter to and from her imaginative boyfriend Boles. As debated above, it seems very strange and awkward for him, so that he always tries to avoid any possible contact with her; even he often looks down on her without knowing real reasons behind her situation, loneliness and isolation. However, one day, having refused to write one of such silly letters, which, he thinks, will deviate him from "the path of righteousness", the boy comes to realize 
that he has made "a great mistake in suspecting her...It was evidently something very different" in her attitudes that "she wanted to say something and couldn't", (235). With the "unpleasant feeling" in his mind, he visits Teresa in her apartment to release himself from the uneasiness, and during the visit, the boy learns the truth and regrets offending her with his indifferent and prejudiced manners towards her: "I understood at last. And I felt so sick, so miserable, so ashamed, somehow. Alongside of me, not three yards away, lived a human creature who had nobody in the world to treat her kindly, affectionately, and this human being had invented a friend for herself!" (237; emphasis added).

As for this indifference, prejudice and "self-sufficiency", Gorky gives us at the end of Her Lover a moral and social lesson applicable to anybody all over the world since we often question moral and social indifference and prejudice towards others in life owing to the fact that it spoils peaceful, harmonious and warm relationships, yet we are also trapped by our "self-sufficiency" and "impeccability": simply, "self-sufficiency" and "impeccability" become an obstacle before us once we strive to understand and communicate with others. For example, the unnamed narrator of the story concludes that "we, wrapped round in the rags of our virtues, and regarding others through the mist of our self-sufficiency, and persuaded of our universal impeccability [perfection, excellence and faultlessness], do not understand this" (237). This statement gives us a message about social life, social responsibility and relationships, a message that encourages us to feel empathy with other and their situations because "the rags of our virtues", together with "the mist of our self-sufficiency", prevent us, like the boy in the story, from appreciating the lives of others as in the case of Teresa. Eventually, Gorky's narrator, in my view, makes a historical statement about the ways we try to judge others as well as about his humanism:

And the whole thing turns out pretty stupidly-and very cruelly. The fallen classes, we say. And who are the fallen classes, I should like to know? They are, first of all, people with the same bones, flesh, and blood and nerves as ourselves. We have been told this day after day for ages. And we actually listen-and the devil only knows how hideous the whole thing is. Or are we completely depraved by the loud sermonising of humanism? In reality, we also are fallen folks, and, so far as I can see, very deeply fallen into the abyss of self-sufficiency and the conviction of our own superiority. But enough of this. It is all as old as the hills-so old that it is a shame to speak of it. Very old indeed-yes, that's what it is! (237-8; emphasis added)

In my view, this quotation obviously touches on two important issues linked to the relationship among individuals in social life. The first one is the view of quality and the inherent right to life whether we are old or young, whether we are fallen or well-off, whether we are weak and strong in our position because all the human beings consist of "the same bones, flesh, and blood and nerves as ourselves". Regardless of their gender, race, religion, social status, and position, therefore, everybody deserves the same attention, concern, esteem, love, care and service; it is in the nature of human beings that they desire to be respected, to be 
taken into consideration, to be appreciated and to be loved, which will noticeably give meaning to their lives and cling them firmly to life, and then they will enjoy equally the graces and beauty of life all together. Gorky stresses all these humanistic views in his letters and works in the face of terror, war, famine and social indifference (Gorky, 1968: 351-3; Edwards, 1902: 234-7). In the story, it is exactly what Teresa would like to achieve in her life; she just looks for "a friend" to love her and communicate with him; she wants to be loved and then be at centre of life and meaning, yet the cruel merciless world, people's "self-sufficiency" and "impeccability" grudge her this beauty and happiness of life and eventually doom her to misery and suffering. Secondly, the quotation above suggests that the discourse of "humanism" is just a "loud" sermon in theory. When it comes to practice, everybody thinks of their own "self-sufficiency" and "superiority" in their relationship with others, so that Teresa for Gorky in the story is not "fallen" as literarily understood but those who have led her to such a dreadful situation by falling her deeply "into the abyss of self-sufficiency and the conviction of our own superiority". Gorky regrets to see this attitude in the case of Teresa because although "It is all as old as the hills-so old that it is a shame to speak of it. Very old indeed-yes, that's what it is!", human beings seem not to have changed their habits and attitudes in positive respective way: that is, human beings have not yet gone beyond their "sermonising" slogans when they come to treat and communicate with others.

In conclusion, Gorky represents a patch of Teresa's life in a plain language. In so doing so, he gives us not only the facets of the world which treats her but also her different attempts and tendencies to lead a peaceful and happy life. In my view, however, Gorky artistically goes beyond the individual representation of Teresa and universalizes the point in a way that anyone in the world may have encountered such a life in the world throughout history. If Teresa's life is considered in a broad sense, for example, it obviously associates with the lives of millions of people in other parts of the world as for suffering, loneliness, indifference, "selfsufficiency", prejudice, callousness, and "superiority" complex and so on as seen through ages. Finally, Gorky does not give us a mere reflection of Teresa's life but becomes artistically critical not only of his own time and Russian society in the early decades of the twentieth century but also of the rest of the world by giving all of us moral, social and humanistic messages and lessons when we come to treat and communicate with one another in life. In this respect, his messages are universal and reminding as well. 


\section{References}

Abrams, M. H. and others (Eds). (1979). The Norton Anthology of English Literature (4 ${ }^{\text {th }}$ Ed.). New York and London: W. W. Norton \& Company.

Allport, Gordon. (1979. ). The Nature of Prejudice. New York: Basic Books.

Balasubramanian, Radha. (Spring 1994). The Early Fiction of Maxim Gorky. Six Essays in Interpretation by Andrew Barratt. The Slavic and East European Journal, Vol. 38, No. 1, pp. 176-177.

Edwards, George Clifton. (April 1902). Maxim Gorky. The Sewanee Review, Vol. 10, No. 2, pp. 234-237.

Goodman, Roger B. (Ed.). (1961). 75 Short Masterpieces: Stories from the World's Literature. New York: Bantam Books

Gorky, Maxim. (1917). "Her Lover." In Best Russian Short Stories. Thomas Seltzer (ed.). New York: Boni \& Liveright, pp. 232-238.

-----------. (July 1968). Gorky - The Humanitarian: (Two Letters by Maxim Gorky). Russian Review, Vol. 27, No. 3, pp. 351-353.

Karlinsky, Simon. (January 1966). Stormy Petrel. The Life and Work of Maxim Gorky by Dan Levin. Russian Review, Vol. 25, No. 1, pp. 88-90.

Muchnic, Helen. (April 1963). Maxim Gorky by Richard Hare. Russian Review, Vol. 22, No. 2, p. 207.

Salgaller, Emanuel. (June 1963). Maxim Gorky: Romantic Realist and Conservative Revolutionary by Richard Hare. Slavic Review, Vol. 22, No. 2, pp. 370-371

Whitfield, Francis J. (Spring 1946). Seven Plays of Maxim Gorky by Alexander Bakshy; Paul S. Nathan; Maxim Gorky. Russian Review, Vol. 5, No. 2, pp. 111-112.

Woolf, Virginia. (1948). Modern Fiction. In The Commond Reader: First Series. London: The Hogarth Press, pp. 184-195.

Yedlin, Tovah. (1999). Maxim Gorky: A Political Biography. Westport, CT.: Praeger Publishers. 